\title{
Arsenic trioxide reduces the invasive and metastatic properties of nasopharyngeal carcinoma cells in vitro
}

C.W. Du' ${ }^{1}$, B.G. Wen ${ }^{3}$, D.R. Li ${ }^{1}$, X. Peng ${ }^{2}$, C.Q. Hong ${ }^{1}$, J.Y. Chen ${ }^{1}$, Z.Z. Lin $^{2}$, X. Hong², Y.C. $\operatorname{Lin}^{1}$, L.X. Xie ${ }^{2}$ M.Y. Wu ${ }^{4}$ and $H$. Zhang ${ }^{5}$

\author{
${ }^{1}$ Laboratory of Cancer Research, ${ }^{2}$ Department of Radiotherapy, Cancer Hospital, \\ ${ }^{3}$ Department of Cancer Molecular Biology, ${ }^{4}$ Department of Pathology, \\ Shantou University Medical College, Shantou, P.R. China \\ ${ }^{5}$ Clinical Research Centre, Division of Dermatology, \\ Department of Biomedicine and Surgery, Linkoping University, Linkoping, \\ Sweden
}

\author{
Correspondence \\ D.R. Li \\ Laboratory of Cancer Research \\ Cancer Hospital \\ Shantou University Medical College \\ No. 7 Raoping Road \\ Shantou \\ Guang Dong 515031 \\ P.R. China \\ Fax: +86-754-856-0352 \\ E-mail: deruili@pub.shantou.gd.cn \\ Research supported by the Shantou \\ University Research and Development \\ Fund (L03002), Medical Science \\ Foundation of Guangdong Province \\ (B2004089) and the Traditional \\ Chinese Medicine Research Fund of \\ Guangdong Province (102053). \\ This study is also part of a major \\ research project of the Shantou \\ Science Technology Committee \\ ([2003]119).
}

Received June 14, 2005

Accepted November 18, 2005

\begin{abstract}
Nasopharyngeal carcinoma (NPC) is notorious for the metastases, which are in close association with Epstein-Barr virus-encoded latent membrane protein 1 (LMP1). Arsenic trioxide $\left(\mathrm{As}_{2} \mathrm{O}_{3}\right)$ has been shown to induce apoptosis and differentiation in NPC xenografts. Then, can it repress the cancer cells' metastasis potential? To elucidate this issue, the present study was performed. LMP1-negative cell line HNE1 and LMP1-positive cell line HNE1-LMP1 were used as in vitro model. Cells ( 1 x $\left.10^{5} / \mathrm{mL}\right)$ were cultured with or without $3 \mu \mathrm{M} \mathrm{As}_{2} \mathrm{O}_{3}$ for $48 \mathrm{~h}$. Then the survival cells were collected to investigate their potential of colony formation, attachment, invasion, and migration. Both confocal immunofluorescence staining and Western blot were used to detect the changes of LMP1 expression. The changes of MMP9 were examined by RT-PCR assay and Western blot. The results were as follow: i) the colony formation inhibition rate $(75.41 \pm 3.9 \%$ in HNE1-LMP1 cells vs $37.89 \pm 4.9 \%$ in HNE1 cells), the rate of attachment (HNE1-LMP1 vs HNE1: $56.40 \pm 3.5$ vs $65.87 \pm 5.9 \%$ ), the invasion inhibitory rate (HNE1-LMP1 vs HNE1: $56.50 \pm 3.7$ and $27.91 \pm 2.1 \%$ ), and the migration inhibitory rate (HNE1-LMP1 vs HNE1: $48.70 \pm 3.9$ vs $29.19 \pm 6.27 \%$ ) were all significantly different between the two cell lines $(\mathrm{P}<0.01)$. ii) LMP1 was down-regulated in $\mathrm{As}_{2} \mathrm{O}_{3}$-treated HNE1-LMP1 cells. iii) The reduction of MMP-9 was found in $\mathrm{As}_{2} \mathrm{O}_{3}$-treated groups, more evident in HNE1-LMP1 cells. Thus, we conclude that $\mathrm{As}_{2} \mathrm{O}_{3}$ can reduce metastasis potential of NPC cells, involving inhibition of MMP-9 expression. LMP1 were also reduced in this process and seemed to enhance anti-metastasis activity of $\mathrm{As}_{2} \mathrm{O}_{3}$.
\end{abstract}

Key words

- Arsenic trioxide $\left(\mathrm{As}_{2} \mathrm{O}_{3}\right)$

- Nasopharyngeal carcinoma

- Metastases

- Latent membrane protein 1

- Metalloproteinase 9 


\section{Introduction}

Nasopharyngeal carcinoma (NPC) is a common cancer in southern China. The disease is notorious for its high invasiveness and metastatic activity. Clinically, tumor cells often disseminate to regional lymph nodes and to distant sites before forming a mass at the primary site. Thus far, radiotherapy or radiochemotherapy is the treatment of choice for this malignancy, but side effects as gastrointestinal toxicity and myelosuppression often lead to the interruption of chemotherapy. In addition, tumor metastasis remains a critical obstacle in clinical radiotherapy or combined radiochemotherapy. When metastatic disease develops after curative radiotherapy, the prognosis is poor. Therefore, a novel therapeutic approach to NPC is strongly desired.

We have reported that arsenic trioxide $\left(\mathrm{As}_{2} \mathrm{O}_{3}\right)$, at the dose of $5 \mathrm{mg} / \mathrm{kg}$, suppressed the growth of NPC xenografts by inducing partial differentiation and apoptosis (1). In our earlier work, the drug was shown to inhibit telomerase activity and to enhance radiation-induced apoptosis $(2,3)$. However, the effects of $\mathrm{As}_{2} \mathrm{O}_{3}$ on NPC cell invasion and metastasis are unclear. In the present study, we investigated the antimetastatic effects of $\mathrm{As}_{2} \mathrm{O}_{3}$ on human NPC cell lines using the Matrigel invasion assay. In view of the important role of latent membrane protein 1 (LMP1) in NPC metastasis, we determined the influence of LMP1 on $\mathrm{As}_{2} \mathrm{O}_{3^{-}}$ mediated anti-metastatic activity.

\section{Material and Methods}

\section{Cell lines}

The HNE1-LMP1 cell line, which is constantly expressing LMP1 by artificially transfecting LMP1 cDNA into HNE1 cells, was investigated as an in vitro model in our study. The parental cell line HNE1, which does not express LMP1, derived from poorly differentiated NPC, was used as control. The two cell lines were established at the Cancer Research Institute of Hunan Medical University (4) and were kindly provided by Professor Y. Cao. Cells were cultured in RPMI 1640 medium with $10 \%$ fetal bovine serum, kept in a humidified atmosphere of $95 \%$ air and $5 \% \mathrm{CO}_{2}$ at $37^{\circ} \mathrm{C}$.

\section{Experimental design}

Both cell lines, at the density of $1 \times 10^{5 /}$ $\mathrm{mL}$, were exposed to $3 \mu \mathrm{M} \mathrm{As} \mathrm{O}_{3}$ for $48 \mathrm{~h}$. Floating cells were then discarded and the residual cells were allowed to grow further. When the residual cells reached confluence they were collected for study. Cells not treated with $\mathrm{As}_{2} \mathrm{O}_{3}$ were used as controls.

\section{Colony formation assay}

About 100 living cells were added to a 60 -mm culture dish containing $5 \mathrm{~mL}$ of culture medium. The dishes were then placed in a humidified incubator containing $5 \% \mathrm{CO}_{2}$ and incubated at $37^{\circ} \mathrm{C}$ for 14 days. The number of colonies containing more than 50 cells in each dish was counted under a microscope. The inhibitory rate (IR) was calculated as follows: IR $(\%)=$ (number of colonies formed in the control group - number of colonies formed in the test group)/number of colonies formed in the control group.

\section{In vitro adhesion assay}

Each well of the 96-well microplates was coated with reconstituted basement membrane Matrigel (Becton Dickinson Labware, Franklin Lakes, NJ, USA), $2 \mu \mathrm{g}$ per well. The coated wells were allowed to dry and appropriate serum-free RPMI 1640 medium was added to each well and incubated for 1 h. The wells were then washed with PBS. Each well containing $4 \times 10^{4}$ cells was incubated for $2 \mathrm{~h}$ at $37^{\circ} \mathrm{C}$ in the presence of $5 \%$ $\mathrm{CO}_{2}$. Wells were washed 3 times with 200 
$\mu \mathrm{L}$ PBS, $40 \mu \mathrm{g}$ MTT was added to each well and the plates were incubated for $4 \mathrm{~h}$ at $37^{\circ} \mathrm{C}$ in the presence of $5 \% \mathrm{CO}_{2}$. The liquid was then removed and $200 \mu \mathrm{L}$ DMSO was added to each well. The absorbance of each well was read with a microplate reader (Bio-Rad 450, Hercules, CA, USA) at $492 \mathrm{~nm}$. Data are reported as the percentage of total cells, assuming that the adhesion of cells in the control treatment represented $100 \%$.

\section{In vitro invasion assay}

Assays were performed with the use of Falcon cell culture inserts (pore size, $8.0 \mu \mathrm{m}$; Becton Dickinson). The chambers were set in a 6-well plate. The upper layer of the culture insert was then coated with $750 \mu \mathrm{g}$ Matrigel, a reconstituted extracellular matrix (Becton Dickinson). Cells were seeded at a density of $2 \times 10^{4}$ cells/well into the upper layer of the culture insert and cultured with serum-free DMEM. Then, $3 \mathrm{~mL}$ of culture medium supplemented with $0.1 \%$ BSA and $250 \mu \mathrm{g}$ solubilized Matrigel was placed into the lower layer of the culture insert as a chemoattractant. After the cells were incubated for $24 \mathrm{~h}$, the remaining cells in the upper layer were swabbed with cotton and penetrating cells in the lower layer were fixed with $95 \%$ ethanol and removed for hematoxylin staining. Cells passing through the Matrigel matrix and each 8 - $\mu \mathrm{m}$ pore of the culture insert were counted using light microscopy. Ten fields per well were counted. The IR was calculated as follows: IR $(\%)=$ (number of penetrating cells in the negative control group - number of penetrating cells in the test group)/number of cells in the penetrating negative control group.

\section{In vitro mobility assay}

The assay was the same as for the invasive procedure described above except that the upper side of the polycarbonate membranes was not coated with Matrigel.

\section{LMP1 expression assay}

To determine whether LMP1 plays a role in the metastatic potential of the cells we first used confocal immunofluorescence staining to detect the changes in LMP1 expression in HNE1-LMP1 cells after $\mathrm{As}_{2} \mathrm{O}_{3}$ treatment. Cells were cultured overnight on a glass coverslip, washed with PBS and fixed in $4 \%$ paraformaldehyde. To display LMP1, the cells were first incubated with anti-LMP1 antibody (DAKO, Glostrup, Denmark) and then reacted with their corresponding FITC-conjugated anti-IgG antibody (DAKO) as secondary antibody. To visualize the nuclei, the cells were stained with $50 \mu \mathrm{g} / \mathrm{mL}$ propidium iodine containing $100 \mu \mathrm{g}$ DNase-free RNase A per $\mathrm{mL}$ and the fluorescent image was observed under a laser-scanning confocal microscope (Ultima 312, Meridian Instruments Inc., Kent, WA, USA) using the following parameters: excited light $488 \mathrm{~nm}$, emission light $530 \mathrm{~nm}$ and pinhole $10-40 \mathrm{~nm}$. Western blotting was then used to analyze the changes in LMP1 expression. The procedure was similar to that used for matrix metalloproteinase 9 (MMP-9) examination, which is described below.

\section{MMP-9 expression assay}

We first determined MMP-9 mRNA levels using semi-quantitative RT-PCR. Total RNA was extracted with Trizol reagent (Gibco BRL, Gaithersburg, MD, USA) according to manufacturer instructions. Reverse transcription was performed with the CASsuper two-step semi-quantitative RTPCR kit (Casarray, Shanghai, China). The primers used for MMP-9 mRNA amplification were (F) 5'-GACTCGGTCTTTGAGG AGCC-3' (R) and 5'-GAACTCACGCGC CAGTAGAA-3' (350 bp) (5). PCR conditions were as follows: $94^{\circ} \mathrm{C}$ for $5 \mathrm{~min}$, followed by 32 cycles at $94^{\circ} \mathrm{C}$ for $30 \mathrm{~s}, 56^{\circ} \mathrm{C}$ for $30 \mathrm{~s}$, and $72^{\circ} \mathrm{C}$ for $45 \mathrm{~s}$, with a final extension 
at $72^{\circ} \mathrm{C}$ for $7 \mathrm{~min}$. Electrophoresis of the RTPCR products was performed on $1 \%$ agarose gel with a size marker under standard conditions. Simultaneously, transcripts encoding $B$-actin were detected in all samples and served as internal controls using the primers 5'-CCT CTA TGC CAA CAC AGT GC-3' (left) and 5'-GTA CTC CTG CTT GCT GAT CC-3' (right).

In addition, SDS-PAGE and Western blot were used to determine whether MMP-9 expression was affected. Cells were collected with a cell scraper and placed in lysis buffer (1 $\mathrm{mM} \mathrm{Na}_{3} \mathrm{PO}_{4}, 20 \mathrm{mM}$ HEPES, $\mathrm{pH}$ 7.4, 1 $\mathrm{mM}$ PMSF, $10 \mu \mathrm{g} / \mathrm{mL}$ leupeptin, and $10 \mu \mathrm{g} /$ $\mathrm{mL}$ aprotinin) for at least $1 \mathrm{~h}$ at $4^{\circ} \mathrm{C}$. The cells were transferred to a clean tube and centrifuged for $30 \mathrm{~s}$ at $1,500 \mathrm{~g}$ to eliminate unbroken cells. The supernatant was incubated on ice for $1 \mathrm{~h}$ and then centrifuged at 10,000 $\mathrm{g}$ at $4^{\circ} \mathrm{C}$ for $5 \mathrm{~min}$ and the supernatant was collected and placed in a new microcentrifuge tube. The protein was stored at $-70^{\circ} \mathrm{C}$. Equal amounts of protein from each cell line were added to $12.5 \%$ polyacrylamide gel. After electrophoresis, proteins were blotted onto PVDF sheets (Amersham Pharmacia Biotech Inc., Piscataway, NJ, USA) at $350 \mathrm{~mA}$ for 1 h. The same antibodies used for immunofluorescence staining were used to detect
MMP-9 in each tumor cell line. Goat antimouse antibody conjugated with horseradish peroxidase was used as the secondary antibody. The protein bands were visualized with ECL plus Western blotting detection reagents (Amersham).

\section{Statistical analysis}

Each assay was performed in triplicate and repeated at least three times. Statistical analysis was performed using the SPSS 10.0 for Windows package. Data are reported as means \pm SD. Statistical differences were evaluated by a one-way analysis of variance (ANOVA) followed by the Bonferroni post hoc test, with the level of significance set at $\mathrm{P}<0.05$.

\section{Results}

\section{Effect of $\mathrm{As}_{2} \mathrm{O}_{3}$ on colony formation}

After $\mathrm{As}_{2} \mathrm{O}_{3}$ treatment, the two cell lines showed different rates of colony formation (see Figure 1). The rate of colony formation inhibition was $75.41 \pm 3.9 \%$ for HNE1LMP1 cells and $37.89 \pm 4.9 \%$ for HNE1 cells, with a significant difference between lines $(\mathrm{P}=0.000)$.

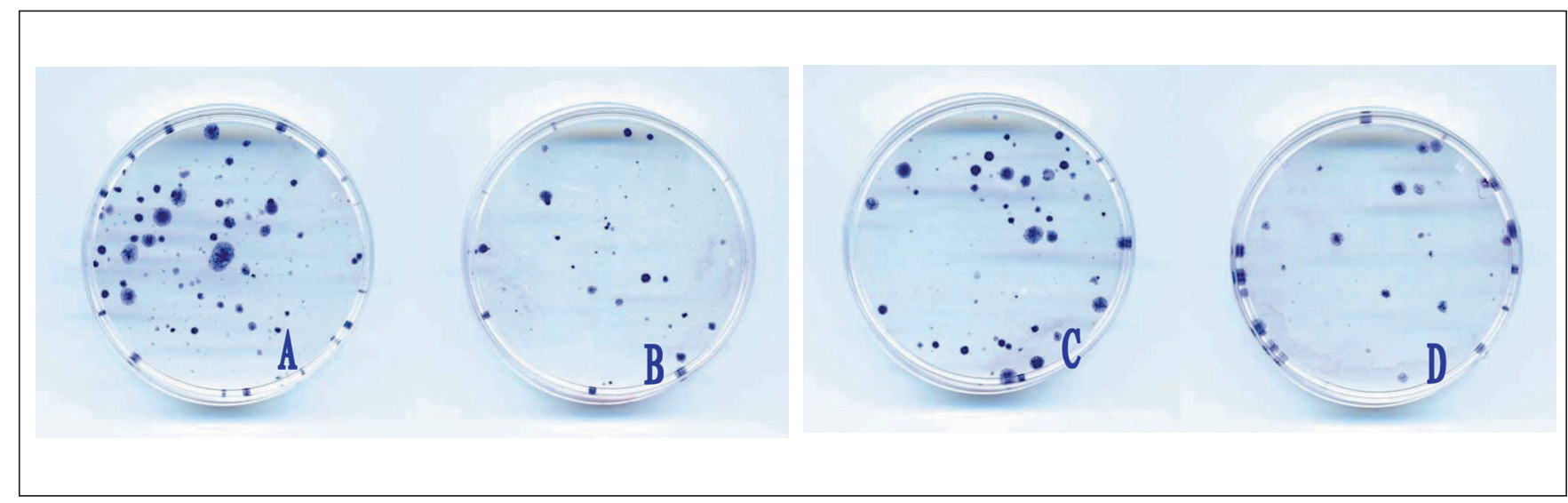

Figure 1. Effect of $\mathrm{As}_{2} \mathrm{O}_{3}$ on nasopharyngeal carcinoma cell colony formation. $A$, Untreated HNE1-LMP1 cells. $B, \mathrm{As}_{2} \mathrm{O}_{3}$-treated HNE1-LMP1 cells. $C$, Untreated HNE1 cells. $D, \mathrm{As}_{2} \mathrm{O}_{3}$-treated $\mathrm{HNE} 1$ cells. The cells were treated with $3 \mu \mathrm{M} \mathrm{As}{ }_{2} \mathrm{O}_{3}$ for $48 \mathrm{~h}$. 


\section{Effect of $\mathrm{As}_{2} \mathrm{O}_{3}$ on adhesion}

The influence of $\mathrm{As}_{2} \mathrm{O}_{3}$ treatment on the adhesion of both cell lines is shown in Figure 2. Both lines showed significantly decreased attachment to Matrigel, with values of $56.40 \pm 3.5 \%$ for HNE1-LMP1 cells and $65.87 \pm 5.9 \%$ for $\mathrm{HNE} 1$ cells $(\mathrm{P}=0.001)$.

Effect of $\mathrm{As}_{2} \mathrm{O}_{3}$ on the invasive ability of the cells

As shown in Figure 3, there were fewer invading HNE1-LMP1 and HNE1 cells in the $\mathrm{As}_{2} \mathrm{O}_{3}$ treatment group compared to the

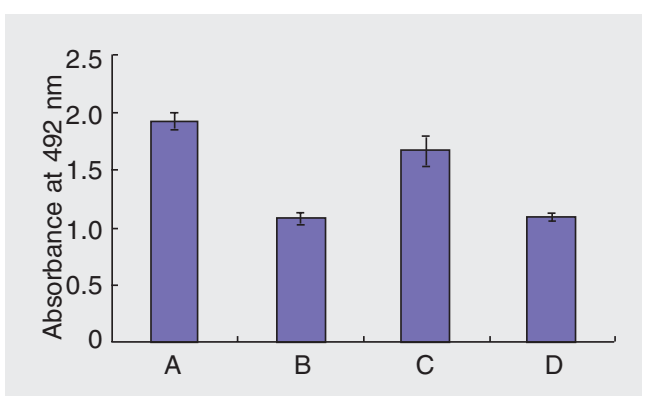

negative control group (HNE1-LMP1: $\mathrm{P}=$ 0.000; HNE1: $\mathrm{P}=0.000)$. However, the invasive ability of HNE1-LMP1 cells was significantly lower than that of HNE1 cells when submitted to treatment with the same dose of $\mathrm{As}_{2} \mathrm{O}_{3}(\mathrm{P}=0.000)$, with respective inhibitory rates of $56.50 \pm 3.7$ and $27.91 \%$ $(\mathrm{P}=0.000)$.

\section{Effect of $\mathrm{As}_{2} \mathrm{O}_{3}$ on cell chemotactic migration ability}

The chemotactic ability of both cell lines after treatment with $\mathrm{As}_{2} \mathrm{O}_{3}$ was lower than

Figure 2. Effect of $\mathrm{As}_{2} \mathrm{O}_{3}(3 \mu \mathrm{M})$ for $48 \mathrm{~h}$ on adhesion in both cell lines. Absorbance of each well was obtained at $492 \mathrm{~nm}$. A, Absorbance for HNE1-LMP1 cells without $\mathrm{As}_{2} \mathrm{O}_{3}$ treatment. $B$, Absorbance for HNE1-LMP1 cells after $\mathrm{As}_{2} \mathrm{O}_{3}$ treatment. $C$, Absorbance for HNE1 cells without $\mathrm{As}_{2} \mathrm{O}_{3}$ treatment. $D$, Absorbance for HNE1 cells after $\mathrm{As}_{2} \mathrm{O}_{3}$ treatment.

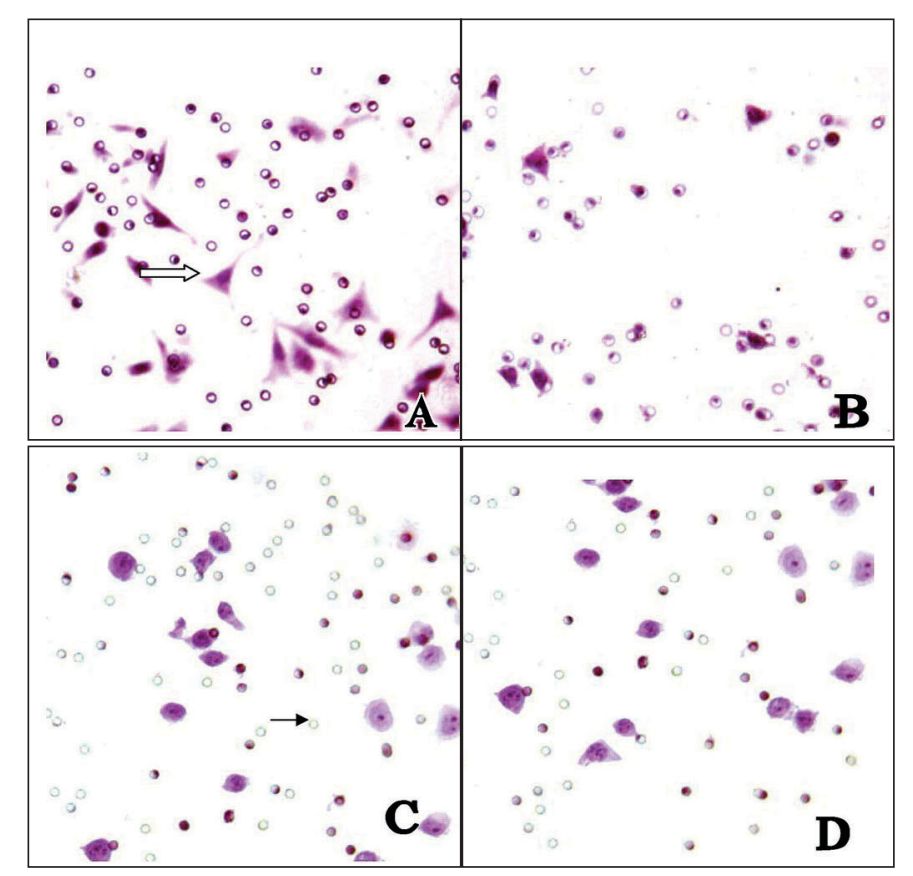

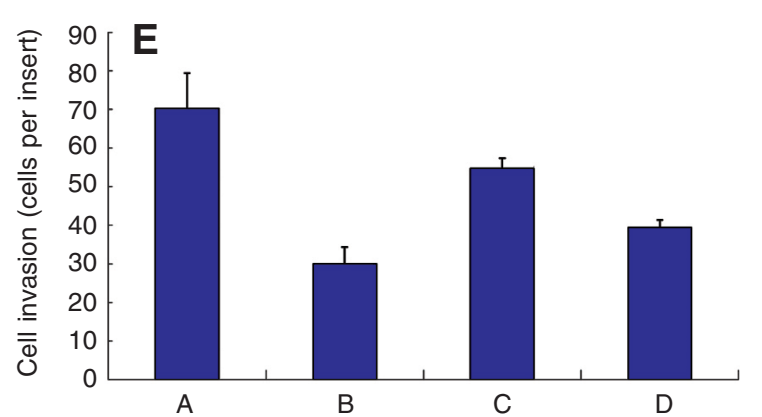

Figure 3. Effect of $3 \mu \mathrm{M} \mathrm{As}{ }_{2} \mathrm{O}_{3}$ for $48 \mathrm{~h}$ on the invasive potential of cells. The assay was performed using Matrigel as reconstituted extracellular matrix in Falcon cell culture inserts in vitro. The small rings are 8- $\mu \mathrm{m}$ membrane pores of the Falcon cell culture inserts indicated by a solid arrow. The invasive cells indicated by an open arrow were counted at least in 10 fields per insert. $A$, Penetrating HNE1-LMP1 cells in the negative control. $B$, Penetrating HNE1LMP1 cells in the $\mathrm{As}_{2} \mathrm{O}_{3}$ group. $C$, Penetrating HNE1 cells in the negative control. $D$, Penetrating $\mathrm{HNE} 1$ cells in the $\mathrm{As}_{2} \mathrm{O}_{3}$ group. $E$, Number of penetrating cells per insert ( $y$-axis) in each group. Data are reported as the mean \pm SD for three independent experiments carried out in triplicate, where A, B, C, and D in the $x$-axis stand for each experimental group described as above. H\&E staining. $\mathrm{P}<0.05$ compared to control (ANOVA). 
that of their negative control group (HNE1LMP1: $\mathrm{P}=0.000$; HNE1: $\mathrm{P}=0.000)$, but the inhibitory rate of HNE1-LMP1 (48.70 \pm $3.9 \%$ ) was significantly higher than that of the HNE1 group $(29.19 \pm 6.27 \%$; $\mathrm{P}=0.000)$. The effects of $\mathrm{As}_{2} \mathrm{O}_{3}$ on the chemotactic migration ability of both cell lines are shown in Figure 4.

\section{Effect of $\mathrm{As}_{2} \mathrm{O}_{3}$ on LMP1 expression}

As shown in Figure 5, the positive staining intensity of HNE1-LMP1 cells markedly decreased after $\mathrm{As}_{2} \mathrm{O}_{3}$ treatment, as demonstrated by confocal microscopy. In parallel, Western blot showed that the level of LMP1 was also reduced.
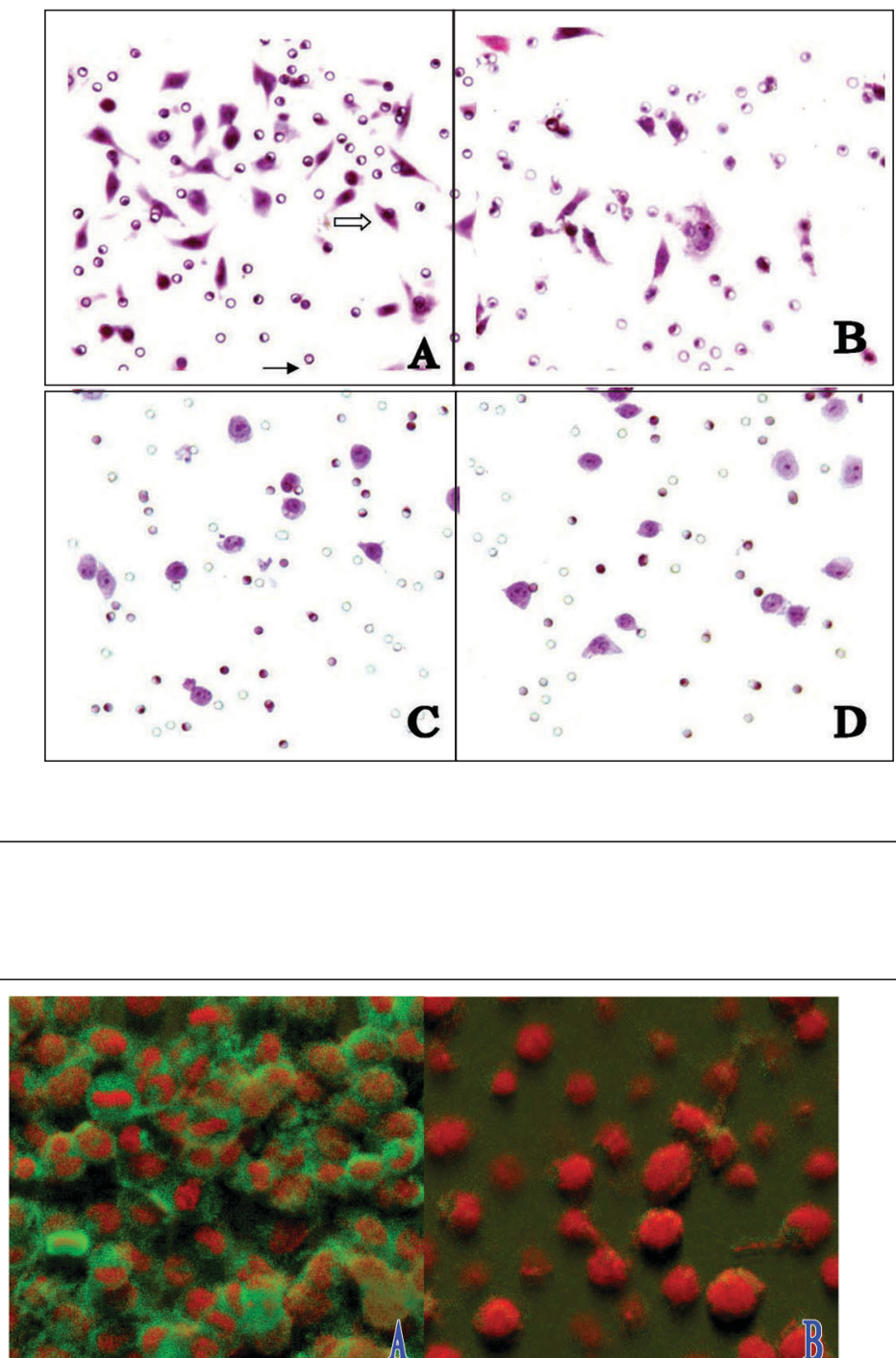
$\triangle B \perp B$

$63 \mathrm{kDa}$

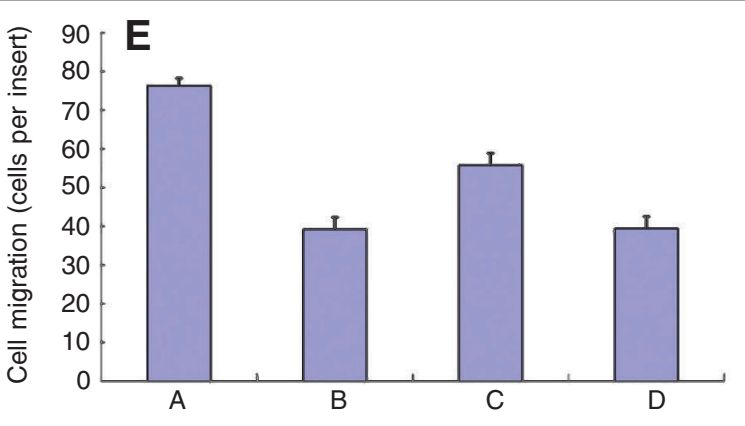

Figure 4. Effect of $3 \mu \mathrm{M} \mathrm{As}{ }_{2} \mathrm{O}_{3}$ for $48 \mathrm{~h}$ on the migration potential of cells. The small rings are $8-\mu \mathrm{m}$ membrane pores of the Falcon cell culture inserts indicated by a solid arrow. The migration cells indicated by an open arrow were counted at least in 10 fields per insert. $A$, Penetrating HNE1-LMP1 cells in the negative control. $B$, Penetrating HNE1-LMP1 cells in the $\mathrm{As}_{2} \mathrm{O}_{3}$ group. $C$, Penetrating HNE1 cells in the negative control. $D$, Penetrating HNE1 cells in the $\mathrm{As}_{2} \mathrm{O}_{3}$ group. $\mathrm{E}$, Number of penetrating cells per insert (y-axis) in each group. Data are reported as the mean \pm SD for three independent experiments carried out in triplicate, where $A, B, C$, and $D$ in the $\mathrm{x}$-axis stand for each experimental group described as above. H\&E staining. $\mathrm{P}<0.05$ compared to control (ANOVA).
Figure 5. Effect of $3 \mu \mathrm{M} \mathrm{As}{ }_{2} \mathrm{O}_{3}$ for $48 \mathrm{~h}$ on LMP1 expressed in HNE1-LMP1 cells. Top panel, Demonstration of LMP1 expression by confocal immunofluorescence staining. The positive signals were green-stained and located in the cytoplasm and membrane (400X). A, Strong green fluorescent intensity for LMP1 signals in untreated cells. $B$, Reduction of green fluorescent intensity for LMP1 signals in $\mathrm{As}_{2} \mathrm{O}_{3}$-treated cells. Bottom panel, Western blott analysis of LMP1 proteins. A, Strong positive staining of LMP1 expression in the control group. $B$, Weak LMP1 expression in the $\mathrm{As}_{2} \mathrm{O}_{3}$ group.

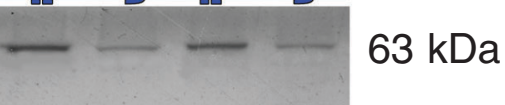




\section{Effect of $\mathrm{As}_{2} \mathrm{O}_{3}$ on MMP-9 expression}

The level of MMP-9 mRNA was examined by semi-quantitative RT-PCR in the HNE1-LMP1 and HNE1 cell lines. As shown in Figure 6, MMP-9 mRNA was expressed in both HNE1-LMP1 and HNE1 cells. However, the extent of expression became very faint in HNE1-LMP1 cells after $\mathrm{As}_{2} \mathrm{O}_{3}$ treatment, whereas $\mathrm{As}_{2} \mathrm{O}_{3}$-treated HNE1 cells showed only moderate reduction of MMP-9 mRNA expression. In addition, tumor cells showed remarkable alteration in the expression of MMP-9 protein. In both cell lines, the expression of MMP-9 protein $(92 \mathrm{kDa})$ decreased after treatment with $\mathrm{As}_{2} \mathrm{O}_{3}$. The down-regulated protein expression of MMP9 was observed particularly in $\mathrm{As}_{2} \mathrm{O}_{3}$-treated HNE1-LMP1 cells (Figure 7).

\section{Discussion}

NPC has highly invasive and metastatic properties and is more metastatic than other head and neck carcinomas. Approximately $90 \%$ of patients show cervical lymph node metastases as the most frequent finding of NPC. At present, radiotherapy remains a standard treatment for this disease. Although intensity modulation radiotherapy delivers a higher conformal radiation dose to the target area and may spare normal organs such as the parotid glands in patients with early stage disease, distant metastases still represent the predominant mode of treatment failure $(6,7)$. Thus, there is a great need for effective antimetastasis treatment for patients with NPC.

$\mathrm{As}_{2} \mathrm{O}_{3}$, a component of Chinese medicine, has been known as a poison for many years. The drug has started drawing more attention since the discovery of its clinical efficacy in acute promyelocytic leukemia reported by Chinese investigators. Clinical trials administering $\mathrm{As}_{2} \mathrm{O}_{3}$ against other blood malignancies and even solid tumors have been conducted in recent years (8). FDA approval of $\mathrm{As}_{2} \mathrm{O}_{3}$ against acute promyelo-

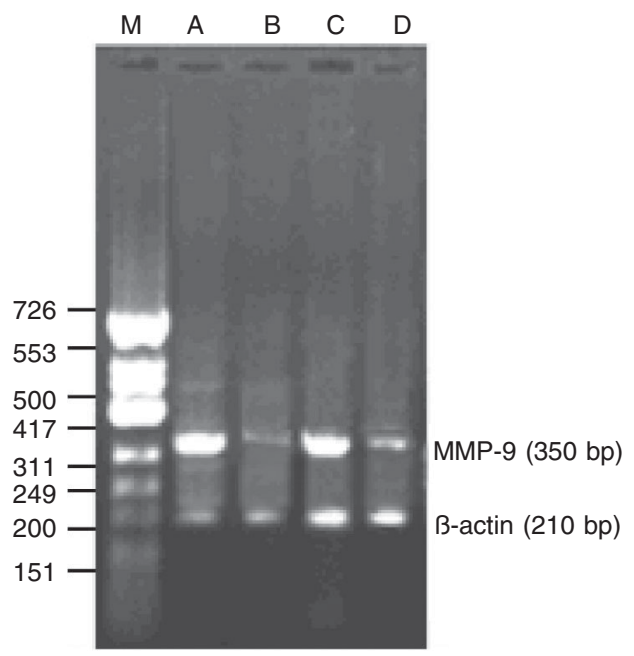

Figure 6. Effect of $3 \mu \mathrm{M} \mathrm{As}{ }_{2} \mathrm{O}_{3}$ for $48 \mathrm{~h}$ on MMP-9 mRNA expression in HNE1-LMP1 and HNE1 cells. $M$, DNA markers. A, Untreated HNE1-LMP1 cells. $\mathrm{B}, \mathrm{As}_{2} \mathrm{O}_{3}$-treated HNE1-LMP1 cells. $C$, Untreated HNE1 cells. $D, \mathrm{As}_{2} \mathrm{O}_{3}$-treated $\mathrm{HNE} 1$ cells. The vertical scale at the left is bp. Experiments were performed on three different occasions with similar results.

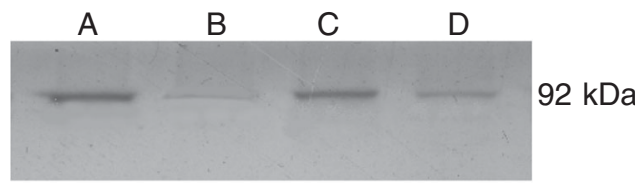

cytic leukemia without major clinical complications has quickly led to the testing of $\mathrm{As}_{2} \mathrm{O}_{3}$ against several types of cancers (9), even though the complete mechanism of action against solid or blood-borne tumors is unclear. At present, the drug is indicated as a broad-spectrum anticancer medicine for a variety of cancers. We have reported that single doses of $5 \mathrm{mg} / \mathrm{kg} \mathrm{As} \mathrm{O}_{3}$ cause apoptosis and differentiation in NPC xenografts $(1,2)$. Moreover, recent data indicated that $\mathrm{As}_{2} \mathrm{O}_{3}$ can induce vascular shutdown and necrosis in esophageal carcinoma (10). In addition, $\mathrm{As}_{2} \mathrm{O}_{3}$ has also been reported to inhibit radiation-induced cell invasion (11). Considering these data as a whole, it was reasonable to investigate whether $\mathrm{As}_{2} \mathrm{O}_{3}$ is able to inhibit the invasive and metastatic activity of NPC cells.

Because we know that not all NPC cells can be induced to apoptosis or differentiation after $\mathrm{As}_{2} \mathrm{O}_{3}$ treatment, the objective of the present study was to determine whether
Figure 7. Western blot showing the effect of $3 \mu \mathrm{M} \mathrm{As}{ }_{2} \mathrm{O}_{3}$ for $48 \mathrm{~h}$ on MMP-9 protein expression in HNE1-LMP1 and HNE1 cells. $A$, Untreated HNE1-LMP1 cells. $B, \mathrm{As}_{2} \mathrm{O}_{3}$-treated HNE1-LMP1 cells. $C$, Untreated HNE1 cells. $D, \mathrm{As}_{2} \mathrm{O}_{3}$-treated $\mathrm{HNE} 1$ cells. 
the malignant biological behavior of residual cells can be changed. Therefore, the present experiment was designed to further extend our previous studies of the inhibitory effects of $\mathrm{As}_{2} \mathrm{O}_{3}$ on cancer cells in NPC, with emphasis on the following points: i) the potential metastatic activity of residual NPC cells after $\mathrm{As}_{2} \mathrm{O}_{3}$ treatment and its possible mechanism, and ii) the role of LMP1 in the anticancer effect of $\mathrm{As}_{2} \mathrm{O}_{3}$.

It is well known that tumor cell metastasis is a complex cascade of events. Essential steps include the degradation of extracellular matrix and basement membrane. The process involves multiple steps such as proliferation, adhesion and migration of tumor cells (11). In the present study, we found that $\mathrm{As}_{2} \mathrm{O}_{3}$ inhibited the cell potential for proliferation, attachment, invasion, and migration. Previous studies have emphasized that the critical step for the control of metastases is to retard local proliferation (12) and to block cell attachment, invasion and motility. Current data indicate that $3 \mu \mathrm{M} \mathrm{As}{ }_{2} \mathrm{O}_{3}$ for 48 h can suppress clonogenic survival, especially in HNE1-LMP1 cells. It has been shown that cellular interactions with extracellular matrix will promote adhesion and migration, which are thought to be required for tumor metastases. Agents inhibiting cell attachment in vitro may decrease the invasion and metastatic potential of tumor cells in vivo (13). In vitro invasion, attachment, proteolytic dissolution of the matrix, and movement of tumor cells through Matrigel and polycarbonate are required. Thus, the reconstituted basement membrane invasion assay could reflect the invasive ability of the tumor. We reported here that, compared with untreated cells, the number of residual HNE1LMP1 and HNE1 cells after the action of $\mathrm{As}_{2} \mathrm{O}_{3}$ treatment through the membrane decreased by up to 1 - to 2 -fold. This is the first evidence that $\mathrm{As}_{2} \mathrm{O}_{3}$ can reduce the invasive potential of NPC tumor cells in vitro.

NPC cells have a unique environment, because most carcinoma cells contain hu- man Epstein-Barr virus as a major etiologic agent for carcinogenesis. Epstein-Barr virus-encoded viral oncoprotein, LMP1, cooperatively induces cellular immortalization and transformation by a series of signal transductions (12). The LMP1 up-regulates vascular endothelial growth factor, cyclooxygenase-2, and interleukin-8 (13-15) that is actively involved in the promotion of angiogenesis. We know that massive formation of blood vessels at the tumor site will increase the opportunity for tumor cells to enter the circulation. Our data showed that $\mathrm{As}_{2} \mathrm{O}_{3}$ inhibited LMP1 expression in HNE1-LMP1 cells. $\mathrm{As}_{2} \mathrm{O}_{3}$-induced metastasis suppression occurred more easily in LMP1-positive NPC cells (HNE1-LMP1) than in the parental cells (HNE1) with no LMP1 expression. Whether microvessel synthesis was inhibited accordingly remains to be determined.

In the present study, we examined the alteration of MMP-9 mRNA levels by RTPCR methods and its protein expression by Western blot, because MMP-9 belongs to a gene family of zinc-containing endopeptidases which can degrade the extracellular matrix and basement membrane, playing an essential role in the metastatic process. On the other hand, many studies have been published about the association of LMP1 and MMP-9 with the invasive and metastatic potential of NPC $(13,16)$. Our data indicated that $\mathrm{As}_{2} \mathrm{O}_{3}$ can down-regulate MMP-9 at the mRNA and protein level in both cell lines to some extent, but with strong inhibition in the HNE1-LMP1 cell line. Based on these findings, we suggest that LMP1 participates in the enhancement of MMP-9 suppression induced by $\mathrm{As}_{2} \mathrm{O}_{3}$. Further studies are needed to clarify how $\mathrm{As}_{2} \mathrm{O}_{3}$ regulates the expression of MMP-9 and how LMP1 increases the sensitivity of $\mathrm{As}_{2} \mathrm{O}_{3}$ in altering the invasive and metastatic properties of NPC cells.

We analyzed the antiproliferative and antimetastatic effects of $\mathrm{As}_{2} \mathrm{O}_{3}$ in NPC cell lines. The down-regulation of MMP-9 by $\mathrm{As}_{2} \mathrm{O}_{3}$ may result in lower invasiveness by 
NPC cells. Our data also demonstrate that LMP1 expression enhances the responsiveness of tumor cells to $\mathrm{As}_{2} \mathrm{O}_{3}$. Based on these results, we present a new point of view about the mechanism of the anti-NPC activity of $\mathrm{As}_{2} \mathrm{O}_{3}$ and provide a logical basis for the application of $\mathrm{As}_{2} \mathrm{O}_{3}$ to the treatment of Epstein-Barr virus-associated NPC.

\section{References}

1. Li DR, Du CW, Lin YC et al. (2002). Inhibition of growth of human nasopharyngeal cancer xenografts in SCID mice by arsenic trioxide. Tumori, 88: 522-526.

2. Du CW, Li DR, Lin YC et al. (2004). Differentiation of human nasopharyngeal carcinoma xenografts and repression of telomerase activity induced by $\mathrm{As}_{2} \mathrm{O}_{3}$. National Medical Journal of India, 17: 6770.

3. Li DR, Lin YC, Xie LX et al. (2003). Arsenic trioxide enhances radiosensitivity in vitro of nasopharyngeal carcinoma. Experimental Oncology, 25: 248-251.

4. Zhu HC, Yao KT, Li GY et al. (1992). Establishment and characteristic analysis of four epithelial tumor cell lines derived from NPC. Journal of Human Medical University (in Chinese), 17: 103-107.

5. Jiang Y, Xu W, Lu J et al. (2001). Invasiveness of hepatocellular carcinoma cell lines: contribution of hepatocyte growth factor, c-met, and transcription factor Ets-1. Biochemical and Biophysical Research Communications, 286: 1123-1130.

6. Kam MK, Teo PM, Chau RM et al. (2004). Treatment of nasopharyngeal carcinoma with intensity-modulated radiotherapy: the Hong Kong experience. International Journal of Radiation Oncology, Biology, Physics, 60: 1440-1450.

7. Lee N, Xia P, Quivey JM et al. (2002). Intensity-modulated radiotherapy in the treatment of nasopharyngeal carcinoma: an update of the UCSF experience. International Journal of Radiation Oncology, Biology, Physics, 53: 12-22.

8. Vuky J, Yu R, Schwartz L et al. (2002). Phase II trial of arsenic trioxide in patients with metastatic renal cell carcinoma. Investigational New Drugs, 20: 327-330.

9. Antman $\mathrm{KH}$ (2001). Introduction: The history of arsenic trioxide in cancer therapy. Oncologist, 6 (Suppl 2): 1-2.

10. Shen ZY, Shen J, Chen JY et al. (2003). The inhibition of growth and angiogenesis in heterotransplanted esophageal carcinoma via intratumoral injection of arsenic trioxide. Oncology Reports, 10: 1869-1874.

11. Wei LH, Lai KP, Chen CA et al. (2005). Arsenic trioxide prevents radiation-enhanced tumor invasiveness and inhibits matrix metalloproteinase-9 through downregulation of nuclear factor kappa B. Oncogene, 24: 390-398.

12. Li HP \& Chang YS (2003). Epstein-Barr virus latent membrane protein 1: structure and functions. Journal of Biomedical Science, 10: 490-504.

13. Lo AK, Huang DP, Lo KW et al. (2004). Phenotypic alterations induced by the Hong Kong-prevalent Epstein-Barr virus-encoded LMP1 variant (2117-LMP1) in nasopharyngeal epithelial cells. International Journal of Cancer, 109: 919-925.

14. Murono S, Inoue H, Tanabe T et al. (2001). Induction of cyclooxygenase-2 by Epstein-Barr virus latent membrane protein 1 is involved in vascular endothelial growth factor production in nasopharyngeal carcinoma cells. Proceedings of the National Academy of Sciences, USA, 98: 6905-6910.

15. Ren $Q$, Sato $H$, Murono $S$ et al. (2004). Epstein-Barr virus (EBV) latent membrane protein 1 induces interleukin-8 through the nuclear factor-kappa B signaling pathway in EBV-infected nasopharyngeal carcinoma cell line. Laryngoscope, 114: 855-859.

16. Horikawa T, Yoshizaki T, Sheen TS et al. (2000). Association of latent membrane protein 1 and matrix metalloproteinase 9 with metastasis in nasopharyngeal carcinoma. Cancer, 89: 715-723. 


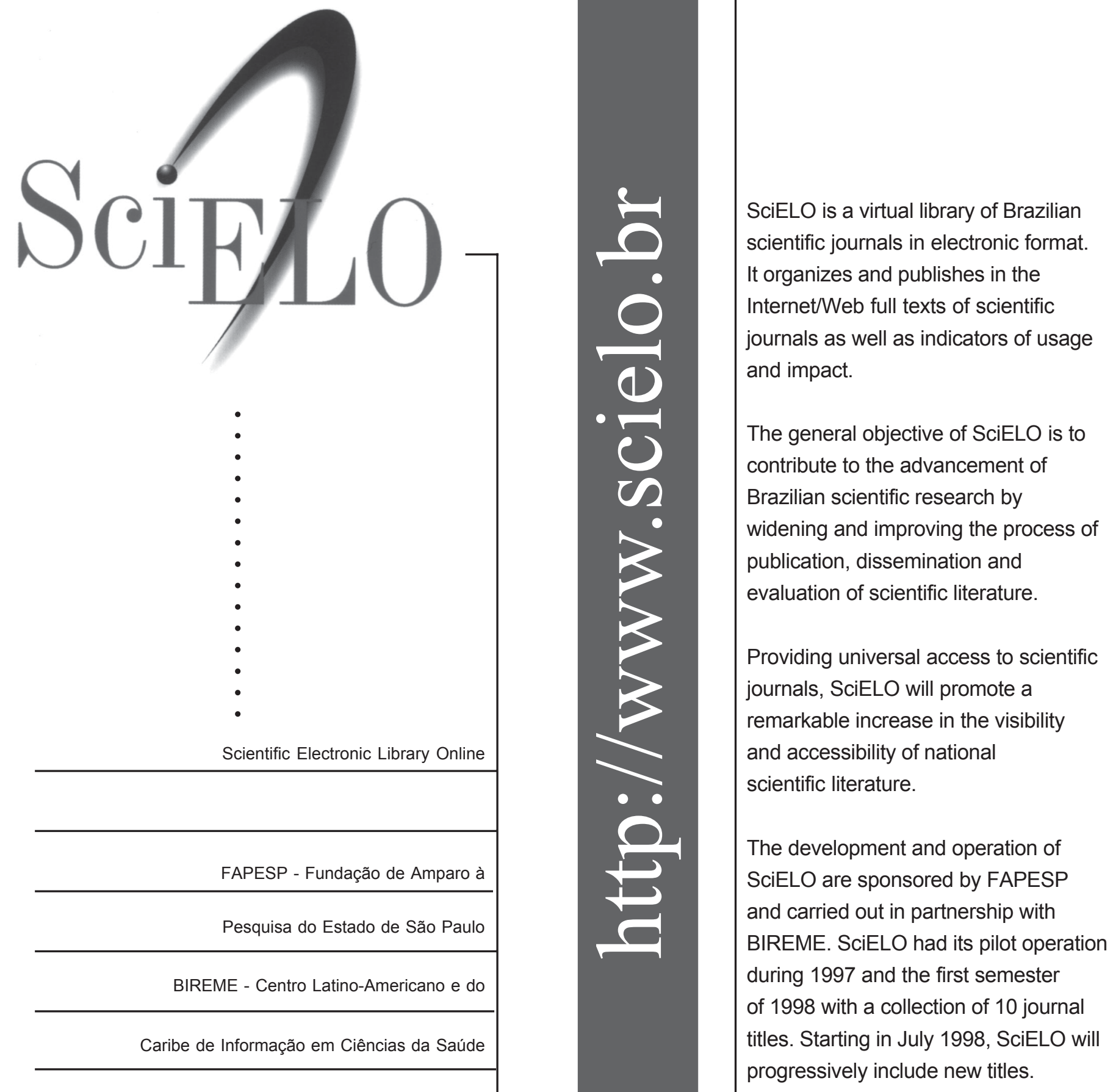

